\title{
Evaluation of Revitalization Strategy: A Case Study of Barukoto Traditional Market in Bengkulu, Indonesia
}

\author{
Amin Shody ${ }^{1}$ Vincentius Totok Noerwasito $^{2}$ and Purwanita Setijanti ${ }^{3}$ \\ Research Scholar ${ }^{1}$ and Professor ${ }^{2,3}$ \\ Faculty of Architecture Design and Planning \\ Department of Architecture \\ Ten November Institute of Technology \\ Surabaya, Jawa Timur \\ Indonesia
}

\begin{abstract}
The Barukoto market is a shopping center that was popular in the 70s to the late 90s in the city of Bengkulu. As time went on, Barukoto Market experienced a deterioration in environmental and physical quality so that it was neglected in several parts. The decline in consumer segmentation that came also decreased, due to the emergence of more modern and representative new shopping centers, such as hypermarkets and shopping malls. To increase the vitality of the area, it is necessary to revitalize activities so that they can create a renewal of the quality and physical quantity of buildings and can increase the property value of the area. To answer the purpose of the study, using qualitative descriptive analysis techniques, supported by quantitative assessment, through the scoring method. The revitalization criteria obtained are, from the location aspect $79.45 \%<80 \%$, this is categorized as a potential enough to do revitalization activities. Furthermore, from the aspect of the physical study, an assessment of $48.50 \%<61 \%$ and management aspects with a value of $50 \%<61 \%$.
\end{abstract}

Key Words: Revitalization, Traditional Markets, propertyvalues, physical aspects, functional.

\section{INTRODUCTION}

Barukoto Market is a traditional shopping and shopping center built by the local government to support the city's functions. Located in the center of the old city of Bengkulu (Hermes, 2002), this market was built in 1978 to fulfill the people's clothing and food needs at that time. Traditional markets as a center for commercial activities play an important role in the development of a city. Traditional markets are places where sellers and buyers meet and are marked by the existence of direct buying and selling transactions and usually there is a bargaining process, consisting of open stalls, basements and basements (Cahyono, 2010).

along with the growth of the city dynamics, and the current of globalization and the diverse needs of the community. (Catenese, 1998). Slowly but surely, the barukoto market began to be abandoned by the people in the period of the 200 s. Changes in consumer behavior that began to diversify and wanted something new triggered the emergence of more modern and representative shopping places such as hypermarkets, supermarkets, trade centers and shopping malls. This is also one of the causes of the increasingly quiet visitors at Barukoto Market. Modern markets are markets that are managed with modern management, generally found in urban areas, as providers of goods and services with quality and better service to consumers. With the existence of a modern community market as consumers, it is increasingly easy to choose a place to shop and get more complete, safe and comfortable facilities (Sinaga, 2006).

Loneliness of visitors makes some traders begin to look for new places that are more attractive, leaving Pasar Barukoto, this has an impact on retribution revenues which are declining, resulting in operational funds issued by the management for building governance activities becoming less than optimal. generally those experienced by the manager include management, spatial planning, development patterns and funding (Zumrotin, 2002). Less funding resulted in maintenance and development activities in parts of the Barukoto Market building being stopped, which resulted in a decrease in the quality of physical and environmental conditions. Some parts of the room are not suitable to be occupied and used by traders. The condition of the merchant kiosk on the second floor is totally paralyzed and has been vacated by traders since 2007 until when the researchers conducted this research 
observation. At present, only the kiosks on the ground floor are still functioning properly. With these conditions, Barukoto Market land use is not optimal and is not profitable for building managers.

Barukoto Market is in a strategic location, located in the old city center area, in the strategic area of Bengkulu's tourism designation, the location around the building adjacent to the tourist attraction set by the local government, such as natural tourism, historical heritage tours and Bengkulu Malay cultural tourism. The object is crowded by local and foreign tourists, with the number of tourists visiting Bengkulu increasing every year. The location adjacent to the tourist area is an added value for the arrangement and development of the Barukoto Market. In addition, the strategic location has the opportunity to be developed from the point of economic interest, as a trade and service area. Therefore, seeing the lack of optimal use of land in the Barukoto Market and the potential for tourism and trade areas that can be added value for development.

Efforts need to be made to improve the physical, environmental and economic productivity of the Barukoto Market structuring and development activities. These activities can be in the form of revitalizing the area and buildings, Revitalization is a series of efforts to reorganize a condition or building that has strategic potential and value by restoring the vitality of a region that has decreased so that these regions obtain optimal added value to economic, social and cultural productivity urban areas (Danisworo, 2002). The revitalization scale has macro and micro levels according to the needs needed. The revitalization process of an area includes improving physical, economic and social aspects. The revitalization approach must be able to recognize and utilize the potential of the surrounding environment related to history, meaning, the uniqueness of the location, and the image of the location that will be revitalized (Martokusumo, 2002). buildings, able to create growth in economic stability and increase the value of regional property by optimally utilizing land functions.

\section{THEORITICAL REVIEW}

\subsection{Revitalizing the area and buildings}

Revitalization is an ongoing program in the short to long term stages and also starts from small spaces to widespread. Revitalization is related to efforts to build and mobilize the strength of local communities to form a healthy life pulse so as to be able to provide socio-cultural and economic benefits for the community (Adhisakti, 1997). According to (Martokusumo, 2008) the revitalization approach must be able to recognize and utilize the potential characteristics of the surrounding area (history, meaning, uniqueness of location and place image), this can be described as follows:

\section{Physical Interevention}

This process reverses the physical nature of revitalization and is carried out in stages, including improving the quality and physical condition of buildings, connecting systems, sign systems and green open spaces. In the revitalization process it is closely related to the formation of regional image, this is related to the visual conditions of the area that can attract visitor activities, therefore physical intervention needs to be done by taking into account the context of the surrounding environment.

2. Economic rehabilitaiton

Revitalization by carrying out physical repairs of places or regions that are short and long term candidates are expected to accommodate formal and informal activities. So that it can provide added value for its development. In the context of revitalization mixed functions need to be developed that can encourage economic activity and new vitality.

3. Social Revitalization/Institutional.

The success of revitalizing an area will be measured if it is able to create an attractive environment, so it is not just to create an attractive place and id, but in these activities must have a positive impact and can improve the dynamics of the social life of the community.

\subsection{Type of Revitalization}

The mismatch might have its source in the physical fabric, or in the economic activities within the fabric. These two different types of mismatch entail different measures towards revitalization:

1. Physical revitalization: adaptation of the physical fabric to contemporary requirements through various modes of renewal.

Possible courses of action to enable this occur can be realized through various modes of renewal, such as :

a) Refurbishment (conservation and consolidation): the physical intervention in the actual fabric of the building to ensure the continued performance of its structure and fabric;

b) Demolition and redevelopment: although this may be an undesirable approach in an historic urban quarter, under certain conditions it might be an inevitable type of intervention within the span of physical revitalization.

c) Conversion (adaptive use): the adaptation of a building to a new function or use. It involves a greater change than refurbishment and restoration. The allowance for change is limited to a number of factors:

- the physical and spatial parameters of the existing building;

- the architectural character of the building and the constraints imposed by special 
- historic building controls on permissible change;

- the planning policy context;

- the environmental consequences of the change of use, particularly in terms of traffic

- generation and management;

- the reception of the commercial market and posible users and investors in the change of use.

2. Economic revitalization: utilization and purposeful occupation of the improved/ enhanced building stock (through physical revitalization) to sustain revitalization in a long-term perspective, and to enable the area to compete with the rest of the city. Depending on the degree of mismatch and the internal/external dynamics that a specific historic urban quarter faces, three different types of modes of renewal in terms of economic activity, that will be referred to as strategic approaches in this paper, can be pursued:

- Functional restructuring: changes in occupation with new uses or activities replacing the former ones.

- Functional diversification: keeping the existing uses to some extent and introducing some new ones.

- Functional regeneration: existing uses remain but operate more efficiently or profitably. (Tiesdell et al., 1996)

The process of revitalizing historic urban quarters involves the integration of the historic legacy, inheritance and sense of place with the demands of contemporary economic, political and social situations. Accordingly, the revitalization process, through which the mismatch between the services offered by the fabric of the historic quarters and the contemporary needs can be reconciled, is a complicated process, since it is concerned with both the (physical) urban fabric and the (economic) activities in a specific historic urban quarter. Depending on whether the mismatch has its source in the physical fabric or in the economic activities within the fabric, different measures towards revitalization will be required

Table 2.1. Types of revitalization

\begin{tabular}{|c|c|c|c|}
\hline \multicolumn{4}{|c|}{ REVITALIZATION } \\
\hline \multirow[t]{3}{*}{ Physical } & \multirow[t]{3}{*}{ Mode of Renewal } & Refurbishment & \multirow[t]{2}{*}{ Rehabilitation } \\
\hline & & Conversion & \\
\hline & & \multicolumn{2}{|c|}{$\begin{array}{c}\text { Demolition } \\
\text { and Development }\end{array}$} \\
\hline \multirow[t]{3}{*}{ Economic } & \multirow[t]{3}{*}{ Strategic Approach } & \multicolumn{2}{|c|}{ Functional Restructuring } \\
\hline & & \multicolumn{2}{|c|}{ Functional Diversification } \\
\hline & & \multicolumn{2}{|c|}{ Functional Regeneration } \\
\hline
\end{tabular}

\subsection{Criteria of Revitalization.}

According to Danisworo (2002), the determination of criteria and plans for regional revitalization can be done by examining the causes of decreasing regional performance. The dimensions of the decline in the performance of an ojek from a part of the city area include the following:

a) Poor physical condition of the environment, meaning that in terms of physical and social infrastructure it is not habitable. These adverse conditions accelerate the process of environmental degradation which is ensured to be counter-productive towards the process of healthy socio-cultural life.

b) The level of building and human density exceeds the carrying capacity of the land and the capacity of the infrastructure (infrastructure and facilities) that exist.

c) The effectiveness of land use is very low, due to a decrease in activities / activities or in other words under utilised. This can also be caused by improper allocation of land functions.

d) Land has the potential to be developed further, because of its strategic location for the development of urban planning and the high level of accelerated development.

e) Adequate land area limits, adequate prices and possible land acquisition processes

f) Having prominent environmental assets, such as historical relics (buildings and environments) that are irreplaceable, for example the typical population traditions, tourist attractions, labor resources and having adequate basic infrastructure.

Specifically, the criteria for determining the area offered can be further detailed based on the following:

a) Structure / Physical: physical deterioration occurs due to time / age, urban development. 
b) Function Aspect: In general, it is caused by the internal and external factors of the region. Internal factors are more caused by buildings not being able to support technically / functionally existing needs and activities. While the external area results in the need for modifications or additions to matters relating to building performance.

c) Legal and institutional aspects: Both are directly related to the functional and physical dimensions. This means that a decrease in function, physical and image can also be caused by improper development policies or the application of inappropriate regional object actions.

e) Image of location Aspect and Location Selection: Area characteristics that have added value for development activities can be in the form of tourist areas, trade, industry and old cities. The existence of location identification is an initial effort that must be done by the district / city government to select and determine the priority of an area will be revitalized.

\subsection{Overview of Traditional Markets.}

According to (Zumrotin, 2002) Traditional markets are markets that are built and managed by the government, private sector, cooperatives or self-help communities with businesses such as shops, kiosks or stalls and tents owned or managed by small and medium-sized traders. Traditional markets contain the meeting place of sellers and buyers with transactions directly and usually there is a bargaining process. Yamati (2011), reveals some of the main problems of traditional markets in Indonesia as follows:

1. Management: Inability to manage Traditional Markets to create a clean, safe, comfortable market, and there is no effort to provide guidance to traders to conduct representative sale and purchase activities.

2. Spatial planning and location: Problems arise from operational procedures, location and availability of unproductive businesses.

3. Patterns of development and funding: Less and limited capital needed by the company for operational and maintenance activities. The low level of business results in constraints on investment growth and development, lack of professionalism, transparency and supervision in traditional market management.

The development of the provision of efficient infrastructure through the involvement of the private sector is nothing but because of fulfilling the wishes of the community, meaning that it is not only efficient and economical but also must have a social dimension. Private involvement in the infrastructure sector is due to the following (Darrin and Mervin, 2001)::

1. Government limitations in financing infrastructure development, on the one hand are caused by limitations in technology, power and funds. Whereas on the other hand the need for infrastructure is increasingly urgent. .

2. Development participation based on community desire (Community Driven Development) through risk sharing which was previously the responsibility of the government, was distributed to the private sector.

3. Motivation of profit from the private sector will encourage managed organizations to be more efficient, transparent and competitive.

4. Capacity Building

5. Goverment Policy

\section{METHODOLOGY}

The strategy in this research is case study or descriptive field research. Case study or field research is intended to intensively learn about the background of the current situation, and position of an event, as well as the environmental interaction of a given social unit of a given nature. According to Yin (1993), case studies can be exploratory and descriptive. In addition, Yin (1993) argues that case studies focus more on trying to answer the questions, how and why, and to some extent also answer what questions. Based on these explanations, it is compatible with this research, especially to knowing the conditions of the settlement in accordance with the criteria of revitalization. In this case, the specific causes of impact that phenomena can be identified by observing, understanding and interpreting in accordance with the condition of the research location.

Barukoto Market Conditions that are used as research objects can be known from the data that has been collected, both primary data and secondary data. From the data that has been collected, interpretations are carried out, both from primary or secondary data using qualitative descriptive analysis and quantitative analysis. The initial stage of the study used a qualitative research strategy, where the data collection techniques used were through observation, interviews and surveys at the research location. Qualitative descriptive analysis is associated with grouping the results of the data according to the indicators on each variable, namely the physical condition of the building and the new market environment, the structure of the function area and the activities of traders, the management aspects and characteristics of the research location.

Furthermore, the results of the qualitative descriptive process are re-used using quantitative techniques to obtain the accuracy of data analysis in numerical and numerical forms. Quantitative analysis techniques are used through scoring / weighting methods, to get an assessment of the results of the categorization of each variable that is more accurate and can be explained in detail. 
Assessment of each variable will give the results of calculations in the form of criteria for evaluating the condition of the building and the surrounding environment.

\section{ANALYSIS}

\subsection{Image of Location.}

The characteristics of tourist areas that are attached to the location of the study also influence the existence of the object of research that will be discussed in this study. The location of the area has a strong character towards tourism objects in the city of Bengkulu and is located within the area of tourism activities. Barukoto's market location is in the center of the old city of Bengkulu, which has historical heritage in the form of old buildings and some of which have become cultural heritage by the local government.

The heritage of the historic building is used as a tourist attraction and has an attraction for tourists visiting the region. Some tourist objects around the research location are Balai Buntar Building and regional square which are used as the center of the traditional ritual activities of Tabot and Melayu culture, natural attractions such as beaches, historical heritage buildings (Fort Marlborough, Thomas Parr Monument, Governor's House, old post office).

The location of the study can be seen in figure 4.1, with the object of research being around tourist objects in accordance with the tourist attraction of each object in the form of:

-Figure A : Nature Tourism (beach), Recreation (resort)

-Figure B : Objects of the Chinatown History Building

-Figure C : Objects of the Marlborough Colonial Heritage Building

-Figure D : Bengkulu's Town Square (place of ritual culture for Tabot)

-Figure E :Tradisional house of melayu culture in Bengkulu

-Figure F : :Pasar Tradisional Barukoto.

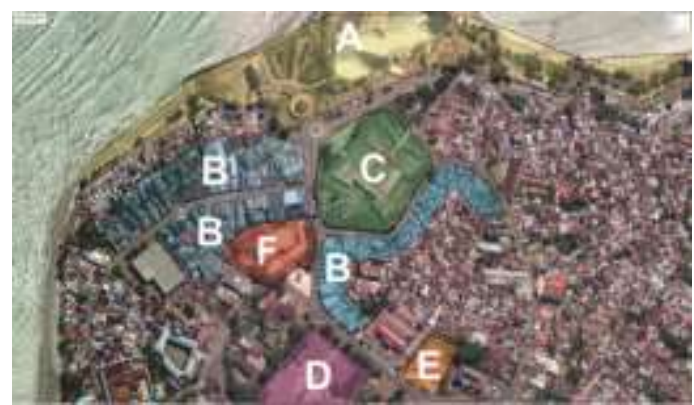

Figure 4.1: Location Characteristics of the Surrounding Area

The location image discussed also has relevance to the identity of the area around the object of research. If you look at figure 4.1 above, it can be identified the characteristics of the area through the function of the type of building and architectural elements in the area. The characteristics of the area can be explained as follows:

\section{Fort Marlborough}

Fort Marlborough is a British colonial heritage building while inhabiting the province of Bengkulu. The fort was founded in 1711-1719 and functioned as the British and Dutch defense headquarters, offices, logistical warehouses to prison functions. The benteg building has details of buildings that are colonial architectural styles from European countries at that time. The fort is on a 4.4 ha land with an altitude of 8.5 meters above sea level, the physical size of the building area reaches 240x 170m.

Until now, marlborough fortress is a historical heritage object that is able to attract tourists. Visitors who come will get interesting experiences from the atmosphere of the place inside the fort. Several parts of the castle building have now been used as museums or galleries that tell how the origin of the arrival of the colonial nation came to Bengkulu, featuring paintings, historical heritage and documentation of past photographs. Visually the Marlborough fort building can be explained as follows :
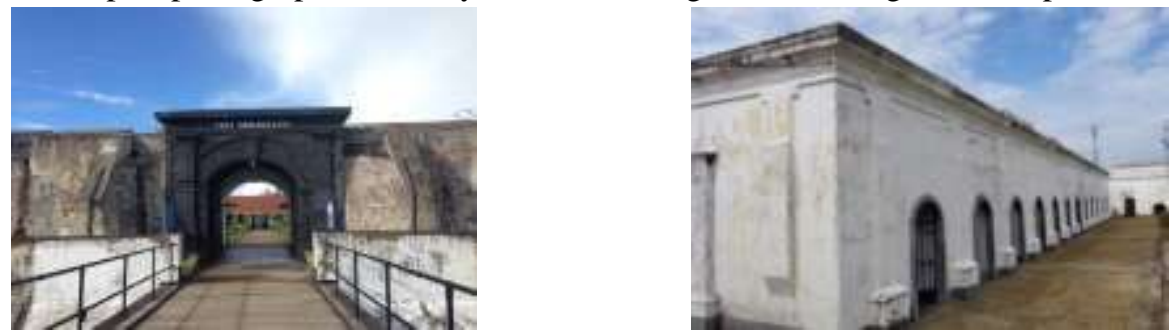

Figure 4.2: Visual Views of Fort Marlborough 
- Symmetrical plans are rectangular, with bastions or guard buildings in every corner of the building

- Has an underground tunnel leading to the coastal area and regional building (governor's house)

- The center of the building is inner court

- Forming architectural elements in the style of colonial buildings, such as arches, arched windows, roofs and many European ornaments.

- The scale of the building is monumental, different from the surrounding buildings.

\section{China Town (Kampung Cina)}

This Chinese village has existed since the colonial era of the British who tried to dominate the pepper trade around the 1600 s. Since its entry into the British East India Company (EIC) trading partnership, more and more people of Chinese descent live in the city of Bengkulu, this happened around 1689. This Chinatown area is very thick with oriental nuances typical of Chinese culture, China. This is evidenced by the typical building of Chinatown with its architectural style.

Consisting of 2-3-storey houses lined up facing the road, the first floor is used as a place of trading activities, while the second floor is used as a place to live (room space). The roof shape of the building resembles a typical Chinese building with gable roofs and repetitions and a shield at the corner of the roof ridge. In this Chinese village area, there are also worship houses such as temples that are used by homeowners around the Pecinan area.. Until now, the Chinatown area is still used by some Chinese descendants for activities in trade and social activities. With historical heritage possessed in the area, it can attract tourists to visit the typical Chinese atmosphere in Bengkulu City.
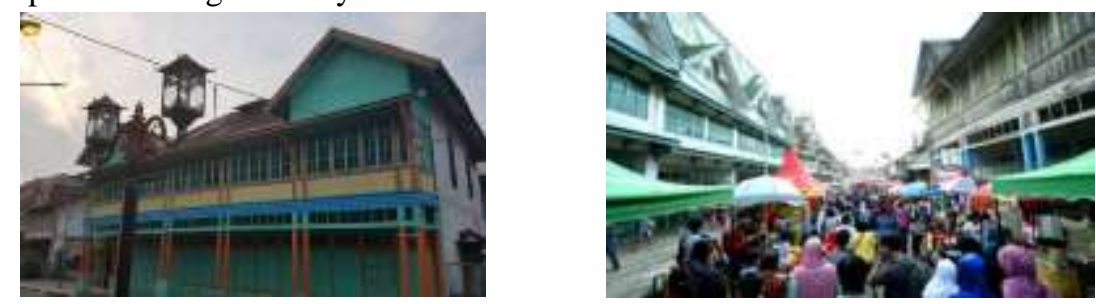

Figure 4.3: Views of Chinatown as an Old City

- Contains a function of the typology of shop houses and residential buildings (row building, extending backward, building height 2-3 floors,)

- Has building functions in the form of temples and buildings for other social activities.

- Affected by the traditional Chinese architectural style with those in China with gable roofs at the peak.

- Chinese-European architectural style, a combination of architectural elements with symmetrical patterns of window and door openings.

- Alkulturation with Chinese architecture / with local locality, can be seen from the facade shape with window openings, wooden doors and niche ornaments typical of Melayu's culture.

\section{The Monument of Thomas Parr}

In 1808 the British established a monument to commemorate the death of their first resident named Thomas Parr, located 100 meters from Fort Marlborough. The Thomas Parr monument is an icon of the old city of Bengkulu, which is in the area of research object. This monument is in the form of a monument which has a long historical value for the struggle of the native people of Bengkulu in fighting the colonoal government at that time. The Thomas Parr octagonal octagonal monument, which covers an area of 70 square meters ( $750 \mathrm{sq} \mathrm{ft}$ ). The monument has a height of 13.5-meters (44 ft) with a dome above it. Currently, the monument is a historical tourist destination for visitors who come to the location of the old city of Bengkulu. It was recorded that the monument was restored by the local government to display its original form which had been neglected due to natural damage.
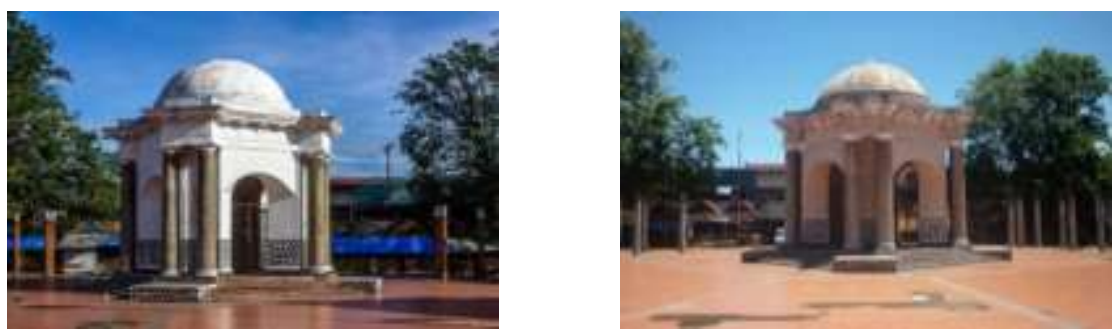

Figure 4.4: Visual appearance of Tugu Thomas Parr 
- The function of the building as a monumental building.

- Around the building there is an open space used for community activities.

- Plans are octagonal or octagonal

- Dome shaped roof

- There are pillars with architectural elements of colonial style.

Based on the discussion of the image of the location in the object research area, the old city area of Bengkulu has an identity or characteristic as the old city center in Bengkulu. This is evidenced by the existence of several historical relics in the form of buildings and monuments that still exist in locations around the object of research. The historical heritage building is currently used as a tourist attraction for tourists who want to visit the old city area. The tourism activities can be a development potential in the object of research by considering the surrounding location has a strategic function from the point of tourism interests in order to increase the property value of the region.

\subsection{Determination of Revitalization Location Assessment}

Location identification is an effort that must be done to select and determine the location of the city area that will be revitalized. Location assessment using scoring assessment is used to get the location of the area that is feasible and has the possibility of revitalization efforts. The steps that can be achieved in identifying locations, as follows:

\subsubsection{Location Assessment (First Stage)}

By evaluating several variables to determine the conditions (1) regional vitality and environmental degradation, (2) location values and (3) regional government commitments, can be explained as follows:

\section{Regional Vitality and Environmental Degradation}

a. Decreasing Economic Productivity

Existing conditions of employment availability, variations in space units and the desirability of local residents.

The potential and problems of economic productivity are calculated from the total value (1.a) multiplied by index $2.22 \%$ with categories being :

- Value $\leq 8.9 \%=$ Low

- Value $>8.9 \%-\leq 15.6 \%=$ Medium

- Value $>15.6 \%=$ High

Table4.1. Decreasing Economic Productivity

\begin{tabular}{|c|c|c|c|c|c|c|c|c|}
\hline \multirow[t]{2}{*}{ No } & \multirow[t]{2}{*}{ Variable } & \multicolumn{6}{|c|}{ Parameters and Values } & \multirow[t]{2}{*}{ Value } \\
\hline & & $\mathbf{P}$ & N1 & $\mathbf{P}$ & N2 & $\mathbf{P}$ & N3 & \\
\hline 1. & Employment & High & 1 & Medium & 2 & Low & 3 & 2 \\
\hline 2 & $\begin{array}{l}\text { Business } \\
\text { room unit }\end{array}$ & $\begin{array}{l}\text { Very } \\
\text { diverse }\end{array}$ & 1 & Variety & 2 & $\begin{array}{l}\text { Less } \\
\text { diverse }\end{array}$ & 3 & 2 \\
\hline 3 & $\begin{array}{l}\text { Population } \\
\text { Density }\end{array}$ & $\begin{array}{l}<60 \text { people / } \\
\mathrm{Ha}\end{array}$ & 1 & $\begin{array}{l}60-150 \\
\text { people / } \\
\text { Ha }\end{array}$ & 2 & $>150 / \mathrm{Ha}$ & 3 & 1 \\
\hline \multicolumn{8}{|c|}{ Total Value (1.a) } & 5 \\
\hline \multicolumn{8}{|c|}{ Indeks } & $2,22 \%$ \\
\hline \multicolumn{8}{|c|}{ Total Value X Indeks } & $11 \%$ \\
\hline
\end{tabular}

Potential and problems related to the decline in economic productivity in the environment around the barukoto market by $11 \%$ with the medium category.

b. Environmental Degradation

Assessment of environmental degradation is based on the conditions of the level of service of infrastructure, facilities, economic, social, cultural and home. The potential and problems of environmental degradation are calculated from the total value (1.b) multiplied by the index $0.83 \%$ with the category can be seen as follows :

- Total index value indeks $8.3 \%=$ Low

- Total index value $>8.9 \%-\leq 14.9 \%=$ Medium

- Total index value> $14.9 \%=$ High 
International Journal of Engineering Research And Advanced Technology, Vol.5, Issue 2, February-2019

Table4.2. Environmental Degradation

\begin{tabular}{|c|c|c|c|c|c|c|c|c|}
\hline \multirow[t]{2}{*}{ No } & \multirow[t]{2}{*}{ Variable } & \multicolumn{6}{|c|}{ Parameters and Values } & \multirow[t]{2}{*}{ Value } \\
\hline & & $\mathbf{P}$ & V1 & $\mathbf{P}$ & V2 & $\mathbf{P}$ & $\mathbf{V 3}$ & \\
\hline & Basic infrastructure & & & & & & & \\
\hline 1. & Clean water infrastructure services in the region & $\begin{array}{l}\text { Very } \\
\text { adequate }\end{array}$ & 1 & Adequate & 2 & Inadequate & 3 & 3 \\
\hline 2 & Road / bridge services in the area & $\begin{array}{l}\text { Very } \\
\text { adequate }\end{array}$ & 1 & Adequate & 2 & Inadequate & 3 & 2 \\
\hline 3 & Drainage infrastructure services in the area & $\begin{array}{l}\text { Very } \\
\text { adequate }\end{array}$ & 1 & Adequate & 2 & Inadequate & 3 & 2 \\
\hline 4 & Sanitation infrastructure services in the region. & $\begin{array}{l}\text { Very } \\
\text { adequate }\end{array}$ & 1 & Adequate & 2 & Inadequate & 3 & 2 \\
\hline 5 & Infrastructure services about waste & $\begin{array}{l}\text { Very } \\
\text { adequate }\end{array}$ & 1 & Adequate & 2 & Inadequate & 3 & 3 \\
\hline 6 & Economic facilities services in the region & $\begin{array}{l}\text { Very } \\
\text { adequate }\end{array}$ & 1 & Adequate & 2 & Inadequate & 3 & 2 \\
\hline 7 & Social and cultural facilities services in the region & $\begin{array}{l}\text { Very } \\
\text { adequate }\end{array}$ & 1 & Adequate & 2 & Inadequate & 3 & 2 \\
\hline 8 & Service means residential houses in the area & $\begin{array}{l}\text { Very } \\
\text { adequate }\end{array}$ & 1 & Adequate & 2 & Inadequate & 3 & 2 \\
\hline \multicolumn{8}{|c|}{ Total Value (1.a) } & 18 \\
\hline \multicolumn{8}{|c|}{ Indeks } & $0,83 \%$ \\
\hline \multicolumn{8}{|c|}{ Total Value X Indeks } & $15 \%$ \\
\hline
\end{tabular}

Based on the assessment of environmental degradation above, the total value (1.a) of the 18 point index value is $0.83 \%$. The total index value is $15 \%$, with a category of high potential value and high problems.

\section{Value of Location}

The assessment of the value of the area based on the strategic function of the area on the variable economic function, the sale value of the land (to the surrounding area with a radius of 1 kilometer), and the achievement of the area from the city center. Potential and problem location values are calculated from the total value multiplied by index $2.22 \%$ and obtain the following values:

- Total index value $\leq 8.9 \%=$ Low

- The total index value $>8.9 \%-\leq 15.6 \%=$ Medium

- Total index value $>15.6 \%=$ High

Table4.3. Value of Location

\begin{tabular}{|c|c|c|c|c|c|c|c|c|}
\hline \multirow[t]{2}{*}{ No } & \multirow[t]{2}{*}{ Variable } & \multicolumn{6}{|c|}{ Parameters and Values } & \multirow[t]{2}{*}{ Value } \\
\hline & & $\mathbf{P}$ & V1 & $\mathbf{P}$ & V2 & $\mathbf{P}$ & $\mathbf{V 3}$ & \\
\hline 1. & Strategic Function & $\begin{array}{l}\text { No potential for } \\
\text { economic } \\
\text { functions }\end{array}$ & 1 & $\begin{array}{l}\text { Enough potential } \\
\text { for the economy }\end{array}$ & 2 & $\begin{array}{l}\text { Potential for } \\
\text { economic functions }\end{array}$ & 3 & 3 \\
\hline 2 & $\begin{array}{l}\text { Land selling value (against } \\
\text { surrounding / } 1 \text { kilometer radius }\end{array}$ & $2 \mathrm{x}$ & 1 & $3 \mathrm{x}$ & 2 & $4 \mathrm{x}$ & 3 & 2 \\
\hline 3 & $\begin{array}{l}\text { Achievements from the } \\
\text { downtown. }\end{array}$ & Inaccessible & 1 & accessible & 2 & Easily accessible & 3 & 3 \\
\hline \multicolumn{8}{|c|}{ Total Value (1.a) } & 8 \\
\hline \multicolumn{8}{|c|}{ Indeks } & $2,22 \%$ \\
\hline \multicolumn{8}{|c|}{ Total Value X Indeks } & $18 \%$ \\
\hline
\end{tabular}

Based on the assessment of location values, the total score is 8 points, with the inex value of $2.22 \%$ and the total value multiplied by the index found at $18 \%$, this indicates that the location value is in the category of high potential / problems. This indicates that the location around the Barukoto market area has a function of economic strategic values that can be utilized more for revitalization activities.

\section{Commitment of Regional Governments / Institution Authorities.}

Table 4.4. Stakeholder commitment

\begin{tabular}{|r|l|l|c|c|}
\hline \multicolumn{1}{|l|}{ No } & \multicolumn{1}{|c|}{ Variable } & Yes & No & Value \\
\hline $\mathbf{1}$ & Sustainable Management & & & \\
\hline a & Plans and guidelines for urban revitalization & $\sqrt{ }$ & & 1 \\
\hline b & Urban Revitalization (if needed) & \multicolumn{2}{|l}{} \\
\hline c & $\begin{array}{l}\text { There is Urban Revitalization Management } \\
\text { within the authorized institution / agency }\end{array}$ & X & 0 \\
\hline & - Promotion & $\sqrt{ }$ & & 1 \\
\hline & - Incentives (waivers, compensation, facilities, awards) & & 1 \\
\hline
\end{tabular}




\begin{tabular}{|c|c|c|c|}
\hline & - Laveraging private sector (partnership) & $\sqrt{ }$ & 1 \\
\hline & - Land secutiy & $\sqrt{ }$ & 1 \\
\hline & - Piloting (Trial/opening) & $\mathrm{x}$ & 0 \\
\hline & - Government office relocation & $\mathrm{x}$ & 0 \\
\hline $\mathrm{d}$ & Public Initiated Strategic area development & $\sqrt{ }$ & 1 \\
\hline $\mathrm{e}$ & Public Initiated Housing development & $\mathrm{x}$ & 0 \\
\hline f & Monitoring and evaluation & $\sqrt{ }$ & 1 \\
\hline & & Total Value1 & 7 \\
\hline & & Indeks & $0,45 \%$ \\
\hline & & $\begin{array}{l}\text { Total value of } \\
\text { Indeks } \mathrm{x} \text { indeks }\end{array}$ & $3 \%$ \\
\hline 2 & Sharing Investation (financing) & & \\
\hline $\mathrm{a}$ & $\begin{array}{l}\text { Not fixated on the state budget, initiative to raise funds from Level One } \\
\text { and Level two (district / city) }\end{array}$ & $\mathrm{x}$ & 0 \\
\hline \multirow[t]{4}{*}{$\mathrm{b}$} & Raising investors & $\sqrt{ }$ & 1 \\
\hline & & Total Value 2 & 1 \\
\hline & & Indeks & $5 \%$ \\
\hline & & $\begin{array}{l}\text { Total value of } \\
\text { Indeks } \mathrm{x} \text { indeks }\end{array}$ & $5 \%$ \\
\hline 3 & $\begin{array}{l}\text { Regulation / Deregulation } \\
\text { (Creating regulation / deregulation that empowers the market by } \\
\text { encouraging the commitment of investors from the community }\end{array}$ & & \\
\hline $\mathrm{a}$ & $\begin{array}{l}\text { The planning document regulation is strengthened by the statement of } \\
\text { the Regional Head }\end{array}$ & $\sqrt{ }$ & 1 \\
\hline \multirow[t]{11}{*}{$\mathrm{b}$} & \multicolumn{3}{|l|}{ Regional Management Regulations } \\
\hline & $-\quad$ Traffic system management & $\sqrt{ }$ & 1 \\
\hline & - $\quad$ Incentives \& disincentives & $\mathrm{x}$ & 0 \\
\hline & $-\quad$ Building permit & $\sqrt{ }$ & 1 \\
\hline & - $\quad$ Retribution & $\sqrt{ }$ & 1 \\
\hline & $-\quad$ Tax & $\sqrt{ }$ & 1 \\
\hline & $\begin{array}{ll} & \text { Land Acquisition } \\
\end{array}$ & $\sqrt{ }$ & 1 \\
\hline & - $\quad$ Ease of Licensing & \begin{tabular}{l|l}
$\sqrt{ }$ & \\
\end{tabular} & 1 \\
\hline & & Total Value 3 & 7 \\
\hline & & Indeks & $0,63 \%$ \\
\hline & & $\begin{array}{l}\text { Total value of } \\
\text { Indeks } \mathrm{x} \text { indeks }\end{array}$ & $4 \%$ \\
\hline \multicolumn{2}{|c|}{ Total Value of the Overall Index } & $\begin{array}{l}\text { Overall } \\
\text { Value }\end{array}$ & $\begin{array}{l}3 \%+5 \\
\%+4 \\
\% \\
=12 \%\end{array}$ \\
\hline
\end{tabular}

\subsection{Location Assessment (Second Stage)}

The second step selection includes additional variables in determining revitalization locations in the Barukoto Market. An assessment of additional variables is intended to determine the existence of the area whether it is included in the strategic spatial planning law, conditions of land ownership and physical density. However, this can be explained as follows:

a) Regions included in Strategic Areas According to the Law on Spatial Planning and national strategic areas. Space Management and national strategic area.The potential of the area entered in the strategic area according to enactment No. 26/2007 on Spatial Planning is obtained from the total value multiplied by the index $1.67 \%$ and categorized into.

-Value of $1.7 \%=$ Low

-Value of $3.4 \%=$ Medium

- Value of $5 \%=$ High

Table 4.5. Strategic Region Categories

\begin{tabular}{|l|l|l|l|l|}
\hline \multicolumn{2}{|l|}{$\begin{array}{l}\text { The area is included in one of the strategic area criteria and } \\
\text { according to the National Strategic Area. }\end{array}$} & Yes & No & Value \\
\hline 1 & National Activity Center Strategic Area & $\sqrt{ }$ & $\mathrm{x}$ & 1 \\
\hline 2 & Regional Activity Center Strategic Area & $\sqrt{ }$ & 1 \\
\hline 3 & Strategic Area of the National Strategic Activities Center & Total Value (1.a) & 0 \\
\hline \multicolumn{2}{|r|}{ Indeks } & $1,67 \%$ \\
\hline \multicolumn{2}{|r|}{ Total Value X Indeks } & $\mathbf{3 , 3 4 \%}$ \\
\hline
\end{tabular}


b) Land Tenure

The valuation of land ownership based on variable ownership status is not in dispute and ownership status is clear. The potential and problems of land ownership in the region are obtained from the total index value of $0.83 \%$ and are categorized as follows :

- Total index value $\leq 2.5 \%=$ Low

-The total index value $>2.5 \%-\leq 4.2 \%=$ Medium

- Total index value $>4.2 \%=$ High

Table 4.6 Land Tenure

\begin{tabular}{|c|c|c|c|c|c|c|c|c|}
\hline \multirow[t]{2}{*}{ No } & \multirow[t]{2}{*}{ Variable } & \multicolumn{6}{|c|}{ Parametres and Value } & \multirow[t]{2}{*}{ Value } \\
\hline & & $\mathbf{P}$ & V1 & $\mathbf{P}$ & V2 & $\mathbf{P}$ & V3 & \\
\hline 1 & Dispute Status & Dispute & 1 & Settlement & 2 & Not & 3 & 3 \\
\hline 2 & Clear Ownership & Not clear & 1 & $\begin{array}{l}\text { Private } \\
\text { property }\end{array}$ & 2 & $\begin{array}{l}\text { State } \\
\text { property }\end{array}$ & 3 & 3 \\
\hline \multicolumn{8}{|c|}{ Total Value (1.a) } & 6 \\
\hline & & & & & \multirow{2}{*}{\multicolumn{3}{|c|}{$\begin{array}{lr}\text { Indeks } \\
\text { Total Value X Indeks }\end{array}$}} & $0,83 \%$ \\
\hline & & & & & & & & $5 \%$ \\
\hline
\end{tabular}

c) Physical Density.

Physical density assessment is based on KDB (Building Base Coefficient) and KLB (Building Floor Coefficient) variables. The potential and problems of land ownership in the region are obtained from the total index value of $0.83 \%$ and are categorized as follows:

-Total index value $\leq 2.5 \%=$ Low

-The total index value $>2.5 \%-\leq 4.2 \%=$ Medium

- Total index value $>4.2 \%=$ High

Table 4.7 Physical Density

\begin{tabular}{|c|c|c|c|c|c|c|c|c|}
\hline \multirow[t]{2}{*}{ No } & \multirow[t]{2}{*}{ Variable } & \multicolumn{6}{|c|}{ Parametres and Value } & \multirow[t]{2}{*}{ Value } \\
\hline & & $\mathbf{P}$ & V1 & $\mathbf{P}$ & V2 & $\mathbf{P}$ & V3 & \\
\hline 1 & $\begin{array}{l}\text { basic } \\
\text { building } \\
\text { coefficient }\end{array}$ & $\begin{array}{l}\text { Low } \\
(<40 \%)\end{array}$ & 1 & $\begin{array}{l}\text { Sedang } \\
(40 \%-60 \%)\end{array}$ & 2 & High $>60 \%$ & 3 & 3 \\
\hline 3 & $\begin{array}{l}\text { building } \\
\text { floor } \\
\text { coefficient }\end{array}$ & Low & 1 & $\begin{array}{l}\text { Medium (1- } \\
\text { 2) }\end{array}$ & 2 & High $>2$ & 3 & 3 \\
\hline \multicolumn{8}{|c|}{ Total Value (1.a) } & 6 \\
\hline \multicolumn{8}{|c|}{ Indeks } & $0,83 \%$ \\
\hline & & & & & & otal Value $x$ & deks & $5 \%$ \\
\hline
\end{tabular}

After evaluating several variables in the first and second stages, the summation of the results of the assessment can be explained as follows:

- Value $\geq 65 \%$ - $\leq 80 \%=$ Sufficiently Potential

- Value $>80 \%-\leq 85 \%=$ Potential

- Value $>85 \%-100 \%=$ Very Potential

Table 4.8 Final Assessment of Revitalization Location Determination

\begin{tabular}{|c|c|c|c|}
\hline No & Assessment Phase & Variable & Total $x$ index value \\
\hline \multirow[t]{4}{*}{1} & \multirow[t]{4}{*}{ Assessment Stage 1} & $\begin{array}{ll}\text { Decreasing } & \text { economic } \\
\text { productivity } & \end{array}$ & $11 \%$ \\
\hline & & $\begin{array}{l}\text { Environmental } \\
\text { Degradation }\end{array}$ & $15 \%$ \\
\hline & & Location Value & $18 \%$ \\
\hline & & $\begin{array}{l}\text { Local Government } \\
\text { Commitment }\end{array}$ & $12 \%$ \\
\hline \multicolumn{3}{|c|}{ Sub total } & $56 \%$ \\
\hline \multicolumn{3}{|c|}{ Percentage } & $\begin{array}{l}(56 / 80) * 100 \% \\
=\mathbf{7 0} \%\end{array}$ \\
\hline \multirow[t]{3}{*}{2} & Assessment Stage 2 & $\begin{array}{l}\text { Strategic area according } \\
\text { to the spatial law }\end{array}$ & $3,34 \%$ \\
\hline & & Type of land ownership & $5 \%$ \\
\hline & & Physical density & $5 \%$ \\
\hline \multicolumn{3}{|c|}{ Sub total } & $13,34 \%$ \\
\hline
\end{tabular}


International Journal of Engineering Research And Advanced Technology, Vol.5, Issue 2, February-2019

\begin{tabular}{|l|c|}
\hline Percentage & $(13,34 \% / 15 \%) * 100 \%=\mathbf{8 8 , 9 \%}$ \\
\hline Total $\left(\frac{\text { Total }((\text { Amount of percentage (assessment stage } 1+\text { rating stage } 2)) / 2}{2}\right)$ & $\frac{(70 \%+88,9 \%)}{2}$ \\
\hline Predicate Potential location & $\mathbf{7 9 , 4 5 \%}$ \\
\hline
\end{tabular}

The total assessment of stage one is $70 \%$, this indicates that the revitalization area can pass into the passing grade with a ratio of $70 \%>60 \%$ and can proceed to the second stage. In the second stage of the assessment, the percentage reached $88.9 \%$. With the total value of the final assessment being estimated at $79.45 \%$. So, the potential for success in evaluating selected locations is in the range category of values $\geq 65 \%$ - $\leq 80 \%$ with sufficiently potential predicate.

\subsection{Physical Assessment of Pasar Barukoto}

\subsubsection{Main Facilities}

Table 4.8 Physical Condition of Main Facilities

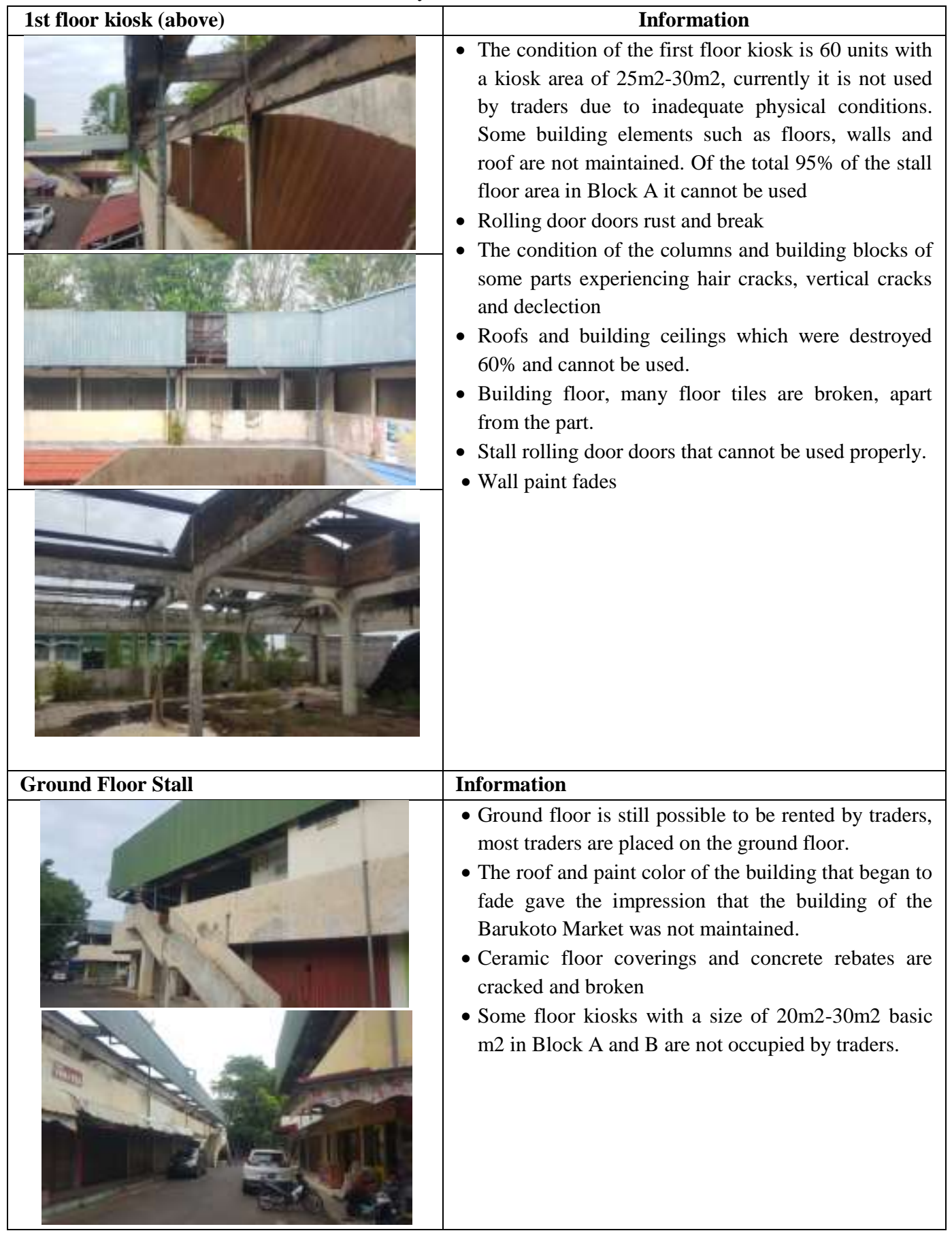




\begin{tabular}{|c|c|}
\hline Warehouse & Information \\
\hline & $\begin{array}{l}\text { - Warehouses that cannot be used and have been } \\
\text { abandoned by renting traders } \\
\text { - Some parts of chipped walls and vertical cracks } \\
\text { - Wall paint fades }\end{array}$ \\
\hline 1st floor kiosk & Information \\
\hline incailit & $\begin{array}{l}\text { - Los traders are located on the } 1 \text { st floor with an area } \\
\text { of } 2,902 \text { square meters. The condition of the empty } \\
\text { booth is not occupied and the supporting elements of } \\
\text { the space are not functioning properly. } \\
\text { - Some building blocks have deflection and hair } \\
\text { cracks } \\
\text { - Roof frames experience corrosion and erosion } \\
\text { - Roof / ceiling coverings are not installed, cracked } \\
\text { and destroyed } \\
\text { - The floor / ceramic floor cover is not properly } \\
\text { installed }\end{array}$ \\
\hline
\end{tabular}

Overall, the observations of researchers in the field, upstairs / 1st floor in Barukoto Market have experienced a decline in physical condition of almost $60 \%$, the building elements of the room are not suitable for use and are not well maintained. Almost all the stalls above cannot be used by traders. The physical deterioration of buildings like this has been going on for a long time. Traders who once rented on this floor chose to leave Barukoto Market and some moved to the ground floor.

Table 4.8 Physical Condition of Main Facilities

\begin{tabular}{|l|c|c|c|c|c|c|c|}
\hline \multirow{2}{*}{$\begin{array}{c}\text { Type of } \\
\text { Characteristics }\end{array}$} & $\begin{array}{c}\text { Structure } \\
(\mathbf{1 - 1 0})\end{array}$ & $\begin{array}{c}\text { Floor } \\
(\mathbf{1 - 1 0})\end{array}$ & $\begin{array}{c}\text { Wall } \\
(\mathbf{1 - 1 0})\end{array}$ & $\begin{array}{c}\text { Roof } \\
(\mathbf{1 - 1 0})\end{array}$ & $\begin{array}{c}\text { MEP } \\
(\mathbf{1 - 1 0})\end{array}$ & $\begin{array}{c}\text { Score } \\
\text { value } \\
(\mathbf{1 - 5 0}) \\
(\mathbf{1 0 0 \%}\end{array}$ & Information \\
\hline $\begin{array}{c}\text { 1st floor kiosk } \\
\text { (Block A) }\end{array}$ & 6 & 4 & 4 & 3 & 3 & $\begin{array}{c}20 \\
(40 \%)\end{array}$ & $\begin{array}{c}\text { Not suitable } \\
\text { for use }\end{array}$ \\
\hline $\begin{array}{c}\text { Ground floor } \\
\text { kiosk } \\
\text { (Blok A \& B) }\end{array}$ & 7 & 6 & 5 & 6 & 6 & $\begin{array}{c}30 \\
(61 \%)\end{array}$ & $\begin{array}{c}\text { Still worth } \\
\text { using }\end{array}$ \\
\hline $\begin{array}{l}\text { Los Traders on } \\
\text { the 1st floor } \\
\text { (Block B) }\end{array}$ & 7 & 4 & 5 & 4 & 3 & $\begin{array}{c}23 \\
(46 \%)\end{array}$ & $\begin{array}{c}\text { Not suitable } \\
\text { for use }\end{array}$ \\
\hline Warehouse & 7 & 5 & 5 & 4 & 4 & $\begin{array}{c}25 \\
(50 \%)\end{array}$ & $\begin{array}{c}\text { Still worthy } \\
\text { with certain } \\
\text { conditions }\end{array}$ \\
\hline
\end{tabular}

With the overall value reached, $n=\frac{20+30+22+25}{200} X 100 \%=48,50 \%<61 \%$

If the percentage score score is below $50 \%$ or as many as 25 points, the physical elements in the building are declared not suitable for use in activities. Based on the results of the scoring above found the highest value found on the merchant floor kiosk on the ground floor with a number of 30 points with a percentage of physical quality of $60 \%$. This is directly proportional to the majority of activities on the ground floor, such as buying and selling activities and building management. Merchant warehouse space has a score of 25 points, at the normal threshold. This room can still be used but certain conditions are carried out such as repairs to roof elements, lighting elements and building floors. For the lowest point, namely the first floor kiosk room with a score of 20 points which is far below the normal threshold percentage of 25 points or $40 \%$. The first floor has not been used in the form of any type of activity, because physical conditions that are not suitable for use by traders or buyers.

Seeing the results of scoring and the percentage of the overall type of characteristics of the building forming physical building elements reached $48.50 \%$. This indicates that the physical structure of the Barukoto Market is still below the standard of physical feasibility as a market building and shopping center.

\subsubsection{Supporting Facilitites}


Table 4.9 Physical Conditions of Barukoto Market Supporting Facilities

\begin{tabular}{|c|c|}
\hline Pedestrian bridge & Information \\
\hline & $\begin{array}{l}\text { - The condition of the pedestrian bridge that } \\
\text { connects the kiosks is not suitable for function } \\
\text { and use. The ceiling and the canopy roof are } \\
\text { not functioning properly. } \\
\text { - Bridge crossing is } 1 \text { unit / } 1 \text { point, cannot } \\
\text { function optimally, to serve consumers who } \\
\text { uphold. }\end{array}$ \\
\hline Corridor & Information \\
\hline & $\begin{array}{l}\text { - Corridors on the } 1 \text { st floor kiosks that are dull, } \\
\text { dirty and poorly maintained. } \\
\text { - The width of the corridor is only } 1.60 \mathrm{~m} \text {. With } \\
\text { a narrow distance, the visitors feel } \\
\text { uncomfortable in shopping. } \\
\text { - The ceiling of the roof of the corridor has not } \\
\text { been maintained, some of the ceiling roofs } \\
\text { have been damaged, the lighting is also not } \\
\text { functioning. }\end{array}$ \\
\hline Stair Access & Information \\
\hline & $\begin{array}{l}\text { - Access to the stairs to the dirty } 1 \text { st floor kiosk } \\
\text { filled with rubbish becomes unkempt and } \\
\text { slums } \\
\text { - Plastered railling walls, fine cracks } \\
\text { - Paint walls are dull and dirty }\end{array}$ \\
\hline Management room & Information \\
\hline & $\begin{array}{l}\text { The office space manager is still actively } \\
\text { functioned as a workplace of employees who } \\
\text { go directly to the field to manage the building. } \\
\text { The area of the room reaches } 120 \mathrm{~m} 2 \text {, which } \\
\text { consists of a living room, staff headroom, } \\
\text { administrative room, archive room and } \\
\text { operational room. }\end{array}$ \\
\hline
\end{tabular}

After the description and analysis of the physical conditions on the elements forming the supporting facilities are found, then scoring is carried out with a scale of values of 1 to 10 . This is done to determine the suitability of the conditions forming the physical elements in the building. The physical feasibility limit is $61 \%$ or equal to 30 points from the accumulated scoring value. If less than that amount is declared not physically feasible.

Table 4.10 Physical Conditions of Supporting Facilities

\begin{tabular}{|c|c|c|c|c|c|c|c|}
\hline \multirow{2}{*}{ Type of Characteristics } & \multicolumn{5}{|c|}{ Element } & \multirow{2}{*}{$\begin{array}{l}\text { Score } \\
\text { value } \\
(1-50) \\
\end{array}$} & \multirow[b]{2}{*}{ Information } \\
\hline & Structure & Floor & Wall & Roof & MEP & & \\
\hline Managament Room & 8 & 7 & 6 & 7 & 7 & $\begin{array}{c}35 \\
(70 \%) \\
\end{array}$ & Still worth using \\
\hline Public Toilet & 5 & 4 & 4 & 6 & 6 & $\begin{array}{c}25 \\
(50 \%)\end{array}$ & $\begin{array}{l}\text { Not feasible with } \\
\text { certain conditions }\end{array}$ \\
\hline Security room & 7 & 6 & 6 & 6 & 6 & $\begin{array}{c}30 \\
(62 \%)\end{array}$ & Still worth using \\
\hline Pedestrian bridge & 5 & 3 & 5 & 4 & 4 & $\begin{array}{c}21 \\
(42 \%) \\
\end{array}$ & $\begin{array}{c}\text { Not suitable for } \\
\text { use }\end{array}$ \\
\hline Kiosk corridor & 6 & 6 & 5 & 6 & 4 & $\begin{array}{c}27 \\
(54 \%)\end{array}$ & $\begin{array}{l}\text { Still worth using } \\
\text { with certain } \\
\text { conditions }\end{array}$ \\
\hline
\end{tabular}


International Journal of Engineering Research And Advanced Technology, Vol.5, Issue 2, February-2019

$$
\begin{aligned}
& \text { With the overall value reached, } n=\frac{35+25+29+21+27}{250} \times 100 \% \\
& \qquad=55 \%<61 \%
\end{aligned}
$$

\subsubsection{Service Facilities}

An assessment of the standard criteria for the physical condition of service facilities and services can be seen as follows:

- Value of 1 (one) = Inadequate

- Value of 2 (two) $=$ Adequate

- Value 3 (three) = Very adequate

- $<61 \%$ of the physical condition is declared to be ineligible

\begin{tabular}{|c|c|c|c|}
\hline $\begin{array}{l}\text { Means of } \\
\text { Utilities and } \\
\text { Services }\end{array}$ & Criteria Standard & Existing Conditions & Assessment \\
\hline \multirow{4}{*}{$\begin{array}{l}\text { Parking slot / } \\
\text { parking } \\
\text { circulation }\end{array}$} & $\begin{array}{l}\text { - A proportional parking area is } \\
\text { available with a ratio of } 1 \mathrm{SRP} \\
\text { to } 100 \mathrm{~m} 2 \text {, needs } 100 \mathrm{SRP}\end{array}$ & $\begin{array}{l}\text { The condition of the parking } \\
\text { slot can load } 82 \text { SRP by off- } \\
\text { street parking on the shoulder } \\
\text { of the road circulating the } \\
\text { building environment. Less } \\
\text { than } 82 \text { SRP }<100 \text { SRP }\end{array}$ & $\begin{array}{l}\text { - Inadequate } \\
(1) / 3\end{array}$ \\
\hline & $\begin{array}{l}\text { - There is a clear separation } \\
\text { between the parking area and } \\
\text { the trading room area }\end{array}$ & - Already clearly separated. & $\begin{array}{l}\text { - } \text { Adequate } \\
(2) / 3\end{array}$ \\
\hline & $\begin{array}{l}\text { Parking area is separated by } \\
\text { type of transport: car, } \\
\text { motorcycle, bicycle, truck. }\end{array}$ & $\begin{array}{l}\text { - Not regulated properly, still } \\
\text { mixed between types of } \\
\text { vehicles. }\end{array}$ & $\begin{array}{l}\bullet \text { Inadequate } \\
\text { (1)/3 }\end{array}$ \\
\hline & $\begin{array}{l}\text { - Have a flat area with no } \\
\text { standing water, parking lines } \\
\text { and clear signposts }\end{array}$ & $\begin{array}{l}\text { - Some parts of the water still } \\
\text { have puddles on the road } \\
\text { surface, not yet complete } \\
\text { parking lots along with marker } \\
\text { signs. }\end{array}$ & $\begin{array}{l}\text { - Inadequate } \\
\text { (1)/3 }\end{array}$ \\
\hline \multicolumn{3}{|l|}{ Total Value } & $\begin{array}{l}5 \text { point } / 12 \\
\text { point }\end{array}$ \\
\hline \multicolumn{3}{|l|}{ Percentage } & $41,60 \%$ \\
\hline \multicolumn{3}{|l|}{ Information } & $\begin{array}{l}41,60 \%< \\
61 \%\end{array}$ \\
\hline $\begin{array}{l}\text { Worship } \\
\text { Room }\end{array}$ & $\begin{array}{ll}\text { There is room for } \\
\text { worship. }\end{array}$ & - $\quad$ Available & $\begin{array}{l}- \text { Adequate } \\
\text { (2) }\end{array}$ \\
\hline \multicolumn{3}{|l|}{ Total Value } & $\begin{array}{l}2 \text { point } / 3 \\
\text { point }\end{array}$ \\
\hline \multicolumn{3}{|l|}{ Percentage } & $66 \%$ \\
\hline \multicolumn{3}{|l|}{ Information } & $66 \%>61 \%$ \\
\hline \multirow[t]{3}{*}{ Pedestrian } & $\begin{array}{l}\text { - Adequate sidewalk width, } \\
\text { pavement road surface with } \\
\text { no puddles, availability of } \\
\text { facilities for disability. }\end{array}$ & $\begin{array}{l}\text { - The width of the sidewalk is } \\
1.60 \text { meters, the sidewalk road } \\
\text { surface has a pool of water, } \\
\text { the means of supporting } \\
\text { disability are inadequate. }\end{array}$ & $\begin{array}{l}\text {-Inadequate } \\
\text { (1)/3 }\end{array}$ \\
\hline & $\begin{array}{l}\text { - Enough lighting is available } \\
\text { at night }\end{array}$ & $\begin{array}{l}\text { - Pedestrian lighting is } \\
\text { insufficient, many PJU lights } \\
\text { are not operating properly }\end{array}$ & $\begin{array}{l}\text {-Inadequate } \\
\text { (1)/3 }\end{array}$ \\
\hline & $\begin{array}{l}\text { - The sidewalk area is free of } \\
\text { obstacles }\end{array}$ & $\begin{array}{l}\text { - Some parts of the sidewalk are } \\
\text { used by traders to sell }\end{array}$ & $\begin{array}{l}\text { - Inadequate } \\
\text { (1)/3 }\end{array}$ \\
\hline \multicolumn{3}{|l|}{ Total Value } & $(3) / 9$ \\
\hline \multicolumn{3}{|l|}{ Percentage } & $33 \%$ \\
\hline \multicolumn{3}{|l|}{ Information } & $33 \%<61 \%$ \\
\hline $\begin{array}{c}\text { Provision of } \\
\text { electricity } \\
\text { facilities } \\
\end{array}$ & $\begin{array}{l}\text { - Availability of adequate } \\
\text { electricity supply from PLN }\end{array}$ & - Available and sufficient & $\begin{array}{l}\text { - Very } \\
\text { Adequate } \\
(3) / 3 \\
\end{array}$ \\
\hline
\end{tabular}

Table 4.11 Physical Conditions of Service Facilities 
International Journal of Engineering Research And Advanced Technology, Vol.5, Issue 2, February-2019

\begin{tabular}{|c|c|c|c|}
\hline & $\begin{array}{l}\text { - Genset engine serves as a } \\
\text { backup of electricity }\end{array}$ & $\begin{array}{l}\text { - The generator engine } \\
\text { sometimes does not function } \\
\text { properly }\end{array}$ & $\begin{array}{l}\text { - Inadequate } \\
\text { (1)/3 }\end{array}$ \\
\hline & $\begin{array}{l}\text { - The power cord and } \\
\text { electrical components are } \\
\text { properly installed }\end{array}$ & $\begin{array}{l}\text { - Electric cables, electrical poles } \\
\text { and electrical components are } \\
\text { installed without disturbing } \\
\text { the smooth running of the } \\
\text { activity }\end{array}$ & $\begin{array}{l}\text { - Inadequate } \\
\text { (2)/3 }\end{array}$ \\
\hline \multicolumn{3}{|l|}{ Total Value } & $(6) / 9$ \\
\hline \multicolumn{3}{|l|}{ Percentage } & $67 \%$ \\
\hline \multicolumn{3}{|l|}{ Information } & $67>61 \%$ \\
\hline \multirow[b]{2}{*}{ Lighting } & - Sufficient natural lighting & - Adequate & $\begin{array}{l}\text { - Inadequate } \\
(2) / 3\end{array}$ \\
\hline & $\begin{array}{l}\text { - Adequate artificial lighting } \\
\text { at night in every area of the } \\
\text { courtyard, around stairs, } \\
\text { toilets, parking }\end{array}$ & $\begin{array}{l}\text { - Many public street lighting are } \\
\text { not functioning optimally, } \\
\text { relying on the lighting of the } \\
\text { merchant's warehouse }\end{array}$ & $\begin{array}{l}\text { - Inadequate } \\
\text { (1)/3 }\end{array}$ \\
\hline \multicolumn{3}{|l|}{ Total Value } & $(3) / 6$ \\
\hline \multicolumn{3}{|l|}{ Percentage } & $50 \%$ \\
\hline \multicolumn{3}{|l|}{ Information } & $50 \%<61 \%$ \\
\hline \multirow[t]{2}{*}{ CCTV } & $\begin{array}{l}\text { - Placed in locations that can } \\
\text { monitor all activities }\end{array}$ & - There is no CCTV camera & $\begin{array}{l}\text { - Inadequate } \\
\text { (1)/3 }\end{array}$ \\
\hline & $\begin{array}{l}\text { - CCTV management that can } \\
\text { be accessed online by market } \\
\text { managers }\end{array}$ & $\begin{array}{l}\text { - Not yet integrated with CCTV } \\
\text { management }\end{array}$ & $\begin{array}{l}\text { - Inadequate } \\
\text { (1)/3 }\end{array}$ \\
\hline \multicolumn{3}{|l|}{ Total Value } & $(2) / 6$ \\
\hline \multicolumn{3}{|l|}{ Percentage } & $33 \%$ \\
\hline \multicolumn{3}{|l|}{ Information } & $33<61 \%$ \\
\hline \multirow{3}{*}{ Drainage } & - There is a drain / manhole & - Available & $\begin{array}{l}\text { - Adequate } \\
(2) / 3\end{array}$ \\
\hline & - Drainage is not blocked & $\begin{array}{l}\text { - Some parts of the gutter are } \\
\text { not smooth if the rainfall } \\
\text { intensity is quite high }\end{array}$ & $\begin{array}{l}\text { - } \text { Kurang } \\
\text { memadai } \\
\text { (1)/3 }\end{array}$ \\
\hline & $\begin{array}{l}\text { - Tidak ada bangunan/kios di } \\
\text { atas saluran drainase }\end{array}$ & $\begin{array}{l}\text { - Stalls, booths, courtyards are } \\
\text { not above the channel / } \\
\text { drainage }\end{array}$ & $\begin{array}{l}\text { - Inadequate } \\
(2) / 3\end{array}$ \\
\hline \multicolumn{3}{|l|}{ Total Value } & $(5) / 9$ \\
\hline \multicolumn{3}{|l|}{$\begin{array}{l}\text { Percentage } \\
\text { Information }\end{array}$} & $55 \%$ \\
\hline \multicolumn{3}{|l|}{ Information } & $55 \%<61 \%$ \\
\hline \multirow{4}{*}{$\begin{array}{c}\text { Waste } \\
\text { management }\end{array}$} & $\begin{array}{l}\text { - Water-resistant, closed and } \\
\text { easily lifted and separated } \\
\text { from the types of organic } \\
\text { and organic waste is } \\
\text { available }\end{array}$ & - Not Available & $\begin{array}{l}\text { - Inadequate } \\
(1) / 3\end{array}$ \\
\hline & $\begin{array}{l}\text { - The trash can must be made } \\
\text { of waterproof material, not } \\
\text { easy to rust, strong, closed } \\
\text { and easy to clean }\end{array}$ & - Available & $\begin{array}{l}\text { - Adequate } \\
\text { (2)/3 }\end{array}$ \\
\hline & $\begin{array}{l}\text { - There is a temporary landfill } \\
\text { / TPS which is strong } \\
\text { waterproof and easy to clean } \\
\text { and easily accessible to } \\
\text { garbage carriers }\end{array}$ & $\begin{array}{l}\text { - There is no representative } \\
\text { garbage collection bin } \\
\text { available. }\end{array}$ & $\begin{array}{l}\text { - Inadequate } \\
(1) / 3\end{array}$ \\
\hline & $\begin{array}{l}\text { - The location of the trash can } \\
\text { is separate from the market } \\
\text { building by having its own } \\
\text { access from visitors' access } \\
\text { and loading and unloading of } \\
\text { goods }\end{array}$ & $\begin{array}{l}\text { - The location of garbage } \\
\text { collection can still be seen by } \\
\text { visitors and causes unpleasant } \\
\text { odors }\end{array}$ & $\begin{array}{l}\text { Inadequate } \\
(1) / 3\end{array}$ \\
\hline \multicolumn{3}{|l|}{ Total Value } & $(5) / 12$ \\
\hline \multicolumn{3}{|l|}{ Percentage } & $41 \%$ \\
\hline \multicolumn{3}{|l|}{ Information } & $41 \%<61 \%$ \\
\hline
\end{tabular}




\begin{tabular}{|l|l|l|c|}
\hline \multirow{2}{*}{$\begin{array}{c}\text { Fire } \\
\text { Extinguisher } \\
\text { System }\end{array}$} & $\bullet \begin{array}{c}\text { Fire extinguishers are } \\
\text { available at several points }\end{array}$ & $\bullet$ Not available & $\begin{array}{c}\bullet \text { Adequate } \\
(2) / 3\end{array}$ \\
\cline { 2 - 4 } & $\bullet$ Sistem fire alarm & $\bullet$ Not Available & $\bullet \begin{array}{c}\bullet \text { Inadequate } \\
(1) / 3\end{array}$ \\
\hline Total Value & $(3) / 6$ \\
\hline Percentage & $50 \%$ \\
\hline Information & $\mathbf{5 0 \%}<\mathbf{6 1 \%}$ \\
\hline
\end{tabular}

Seeing the comparative analysis above, the physical aspects of Barukoto Market are of particular concern and have decreased in terms of quantity and quality. This decline occurs almost every year when rolling and makes the new baroto market increasingly poorly maintained and poor governance. Some facilities facilities are indicated below $61 \%$ as a standard for assessing new market building requirements. Main facilities, supporting facilities, utilities and services are currently available. there is still a deterioration in physical conditions seen from the analysis indicators. This is far from the standard category of market facilities / infrastructure as a shopping center which has been released by several stakeholders related to the authority to regulate and manage new markets. 1. It is necessary to increase the physical quality of buildings to attract visitors' attention and provide a comfortable feeling for shopping.

\subsection{Assessment of Management Aspects}

Implementation of policies that have been carried out by managers for the past 2 years for all activity activities based on implementation in the field. In relation to these provisions, there needs to be an emphasis on the implementation of market management, especially those relating to the empowerment of traders and market development. An assessment of the standard criteria for institutional or policy aspects can be seen as follows:

- Value of 1 (one) = Inadequate

- Value of 2 (two) = Adequate

- Value 3 (three) = Very adequate

- $<61 \%$ of institutional aspects are well implemented in the field. The processed data from several policies related to management activities can be explained in the following table:

Table 4.11 Implementation Value of Barukoto Market Management Aspects

\begin{tabular}{|c|c|c|c|c|}
\hline No & Variable & $\begin{array}{c}\text { Indicator } \\
\text { Requirements }\end{array}$ & Existing conditions & Assessment \\
\hline \multirow[t]{4}{*}{1} & \multirow[t]{4}{*}{$\begin{array}{l}\text { Empowerment } \\
\text { of Traders }\end{array}$} & 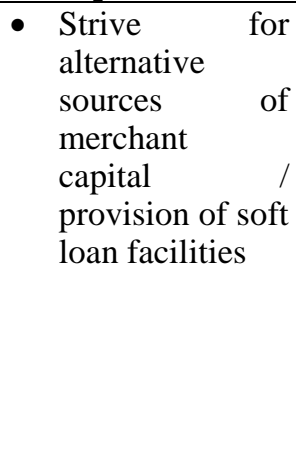 & $\begin{array}{l}\text { Capital and market financing } \\
\text { derived from lease income levies } \\
\text { by traders are less than optimal, } \\
\text { most of the merchant kiosks } \\
\text { experience a decrease in physical } \\
\text { conditions and occupancy, the } \\
\text { amount of rented space is low } \\
\text { It is still limited by relying on } \\
\text { annual budget funds from the } \\
\text { Bengkulu City APBD or special } \\
\text { allocation funds from the central } \\
\text { government. }\end{array}$ & $(1) / 3$ \\
\hline & & $\begin{array}{l}\text { - Increased } \\
\text { competence, } \\
\text { periodic } \\
\text { knowledge in } \\
\text { accordance with } \\
\text { complaints and } \\
\text { complaints of } \\
\text { traders }\end{array}$ & $\begin{array}{l}\text { There are, activities carried out by } \\
\text { the relevant agencies, but activities } \\
\text { are not routinely carried out. }\end{array}$ & $(1) / 3$ \\
\hline & & $\begin{array}{l}\text { - Fostering } \\
\text { traders in order } \\
\text { to utilize the } \\
\text { market area }\end{array}$ & $\begin{array}{l}\text { There are, activities carried out by } \\
\text { related agencies, but activities are } \\
\text { not routinely carried out due to } \\
\text { budget constraints and weak human } \\
\text { resources. }\end{array}$ & $(1) / 3$ \\
\hline & & $\begin{array}{l}\text { - Assistance with } \\
\text { the availability } \\
\text { and smooth } \\
\text { distribution of } \\
\text { goods and }\end{array}$ & $\begin{array}{l}\text { Assistance is allocated regularly } \\
\text { from the local government with the } \\
\text { amount set by the available budget. }\end{array}$ & $(2) / 3$ \\
\hline
\end{tabular}




\begin{tabular}{|c|c|c|c|c|}
\hline & & services. & & \\
\hline \multicolumn{4}{|c|}{ Total Value } & $(5) / 12$ \\
\hline \multicolumn{4}{|c|}{ Percentage } & $41,60 \%$ \\
\hline \multicolumn{4}{|c|}{ Information } & $<61 \%$ \\
\hline \multirow[t]{5}{*}{2} & \multirow[t]{5}{*}{$\begin{array}{l}\text { Management, } \\
\text { maintenance } \\
\text { and } \\
\text { construction of } \\
\text { new market } \\
\text { areas }\end{array}$} & $\begin{array}{l}\text { - standards } \\
\text { (SOPs) describe } \\
\text { tasks and work } \\
\text { methods that are } \\
\text { well- } \\
\text { documented and } \\
\text { easily } \\
\text { accessible. }\end{array}$ & $\begin{array}{l}\text { - Some SOPs have not been well } \\
\text { documented, there are no special } \\
\text { SOPs that regulate market } \\
\text { facilities maintenance, billboard } \\
\text { arrangements, } \\
\text { arrangements, waste / warking } \\
\text { management, and fire prevention. } \\
\text { - Ability of technical human } \\
\text { resources is still not optimal. }\end{array}$ & $(1) / 3$ \\
\hline & & $\begin{array}{l}\text { - Completeness } \\
\text { of the } \\
\text { management } \\
\text { structure for } \\
\text { administration } \\
\text { based on market } \\
\text { type } \\
\text { requirements }\end{array}$ & $\begin{array}{l}\text { - The current management } \\
\text { structure includes the Head of the } \\
\text { Market UPTD, the UPTD Head } \\
\text { of Subdivision and other fields }\end{array}$ & $(3) / 3$ \\
\hline & & $\begin{array}{l}\text { - Amount of } \\
\text { active managers } \\
\text { in the field }\end{array}$ & $\begin{array}{l}\text { - Some staff working in the field } \\
\text { related to information services on } \\
\text { maintenance, hygiene, order / } \\
\text { security and community } \\
\text { development are not available } \\
\text { properly. }\end{array}$ & $(1) / 3$ \\
\hline & & 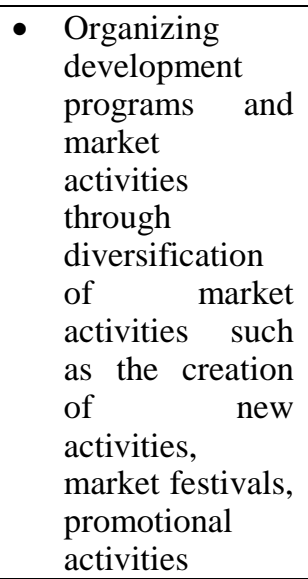 & $\begin{array}{l}\text { - There are no / not yet available } \\
\text { special agenda regularly and } \\
\text { planned related to the creation of } \\
\text { new activities, the } \\
\text { implementation of events / } \\
\text { festivals and promotional } \\
\text { activities is still not extensive and } \\
\text { not yet effective and on target }\end{array}$ & $(1) / 3$ \\
\hline & & $\begin{array}{l}\text { Supervise, } \\
\text { zoning, and } \\
\text { arranging goods } \\
\text { in an orderly } \\
\text { manner } \\
\text { according to the } \\
\text { products on } \\
\text { sale. }\end{array}$ & $\begin{array}{l}\text { - The program of supervision } \\
\text { activities is still limited, human } \\
\text { resource capacity is still weak }\end{array}$ & $(2) / 3$ \\
\hline \multicolumn{4}{|c|}{ Total Value } & $(9) / 18$ \\
\hline \multicolumn{4}{|c|}{ Percentage } & $50 \%$ \\
\hline \multicolumn{4}{|c|}{ Information } & $<61 \%$ \\
\hline
\end{tabular}

\section{CONCLUSION}

From the results of this study, it was found that barukoto market conditions have decreased in vitality, including the planned revitalization criteria.

- Based on the discussion of the image of the location in the object research area, the old city area of Bengkulu has an identity or characteristic as the old city center in Bengkulu. The historical heritage building is currently used as a tourist attraction for tourists who want to visit the old city area. The tourism activities can be a development potential in the object of research by considering the surrounding location to have a strategic function in terms of tourism interests in order to increase the property value of the region. 
- Criteria that have been fulfilled from the revitalization activities include fulfilling the physical aspects, function aspects, institutional aspects and location aspects. The results of the location identification indicate that Barukoto Market is a potential location for revitalization activities, with the final result of the evaluation being $79.45 \%$. This number indicates that the potential success of revitalization activities in selected locations is potential to be developed from the perspective of economic and tourism interests.

- Barukoto Market in each building physical element consisting of the main facilities, supporting facilities and service facilities, shows that the physical condition of the Barukoto Market is below $61 \%(<61 \%)$ so that it is feasible to carry out revitalization plan activities.

\section{REFERENCES}

[1] Budiharjo, Eko. “Konservasi Lingkungan dan Bangunan Kuno Bersejarah di Surakarta”. Gadjah Mada University Press. Yogyakarta. 1989

[2] Cresswell, "Research Design : Qualitative and Quantitative, Mixed Methods. Yogyakarta, Pustaka Pelejara, 2013.

[3] Douglas, P., “ Tourist Development”. New York, Jhon Willey and Son”, 1997.

[4] Francis, J.C . Investment : Analyis and Management, , 5th Edition. McGrawHill Inc., Singapore. 1991.

[5] Groat, L. \& Wang, D. “Architectural Research Methods, 2nd Edition”. New Jersey : Jhon Wiley \& Sons, Inc., 2013

[6] Inskeep, Edward.. "Tourism Planning, an Integrated and Sustainable Development Approach". Van Nostrand Reinhoid. New York. 1991.

[7] Samadi, Z. "Revitalization of Urban Public Spaces : An Overview” Asian Conference on Environment-Behavior Studies. AcE-Bs2015, p. 360-367. 2015

[8] Martokusumo, W. "Revitalisasi Sebuah Pendekatan Dalam Peremajaan Kawasan. Jurnal Perencanaan Wilayah dan Kota”, Vol.19/No.3 Desember 2008, hal 57-73. 2008.

[9] Naciye, Doratli. "Revitalizing Historic Urban Quarters : A Model for Determining the Most Relevant Strategic Approach. European Planning Studies". Vol 13, No.5, p. 749-722. 2005.

[10] Tiesdell, S., T. \& Heath, T.. “ Revitalizing Historic Urban Quarters”, Cornwall, Architecture Press. 1996.

[11] Vileniske, et al. "Architectural Heritage as a Socioeconomic Oppurtinity for Revitalization of Historic Urban Centres : a Global Perspective”. Scientific Journal Of Riga Technical University. Vol.5, p. 27-37, 2001.

[12] Wadu, M. \& Esther, K." "Effect of Revitalization of Historic Building on Retail Shop Values in Urban Renewal : An Empirical Analysis". MDPI Suistainalitiy. Vol. 10, No. 14, . 1-18, 2018.

[13]Zumrotin, K., S. “ Pola Keterkaitan Pasar Modern dengan Pasar Swalayan, Diklat Manajemen Pasar Daerah. Badan Pendidikan dan Pelatihan Dalam Negeri, 2002. 